\title{
Jaworzno. Invisibility
}

\author{
"I demand that no one \\ writes about it at all". \\ Salomon Morel ${ }^{1}$
}

\section{In Native Realm, Czesław Miłosz reminisced:}

Once we caught sight of a local concentration camp that stood on a plain. A column of prisoners was just returning from work. As they passed through the gates, their singing, which contrasted sharply with their gray, extinguished faces, cut me to the quick. Guards armed with rifles and whips completed the procession. ${ }^{2}$

That sight inspired him to write in 1940 a poem entitled Rzeka (River), one of the first works in Polish literature presenting the internees at German Lagers. The following is a fragment thereof:

You can hear song. It is coming. And closer still

A column, in a tired staggering step,

With shovels on their backs, covered by the autumn

Ash. Tattered, dirty, indifferent

They step into the shadows of ruts. The song thumps over them,

Torn from their mouths with a command which cannot change their faces.

They sing, and peer into the depths of silence.

In the front, a guard with an order, drags a long whip

In a sagging hand. And in a shaded river

${ }^{*}$ Associate Professor; Chair of Polish Literature of the $20^{\text {th }}$ and $21^{\text {st }}$ Century, Institute of Polish Philology and Speech-Language Pathology, University of Łódź; arkadiuszmorawiec@poczta.fm.

${ }^{1}$ S. Morel, statement of 1990, in: G. Kuźnik, Hektary Morela (10 reportaży o COP Jaworzno), [missing publisher, place and year of publication], p. 44, http://www.sbc.org.pl/dlibra/plain-conten$\mathrm{t}$ ? id=73070 [accessed on 18.11.2016]. [English version translated from Polish] Between February 1949 and November 1951, Salomon Morel was the Chief Officer of the Central Labour Camp in Jaworzno. In 1996, Polish public prosecutor's office accused him of genocide in relation to his prior function of chief of the Labour Camp in Świętochłowice, which included him personally killing the internees - vide M. Wyrwich, Eagier Jaworzno, $2^{\text {nd }}$ edition, Oficyna Wydawnicza Rytm, Warsaw 2013, pp. 68-72.

${ }^{2}$ C. Miłosz, Native Realm. A Search for Self-Definition, trans. C.S. Leach, University of California Press, Berkeley 1981, p. 226. 
Of the sunset the barrel shall glisten from behind the shoulder.

Oh, they are obedient. Body used to torture

grasps breeziness. They end their - common - day.

$[\ldots]$

Until they step in between the wire. [...]. ${ }^{3}$

Ten years later Sławomir Mrożek saw a similar column. In a story published in 1985 in the Paris-based Kultura, he wrote:

We overtook a train of people marching four abreast, very interesting in terms of its aesthetics as it featured a range of greys, whites, mould, and whole wheat flour. Grey hats without shades, grey overalls, grey clogs, and faces matching the tones. [...] Between the hat and the collar, there was no space for a face, only that continuity of greyness. Normally, faces are either thin or thick, while they were all similarly oblong, meaning not thick, because not due to nutrition but swelling. So it was not as if people were walking, but rather stuffed sacks, without any human expressions, moving identically and mechanically. In a vivid contrast to the mannequins, several human figures marched on the sides of the train. Green uniforms, red faces, and their rifles primed and ready.

"It's those from Jaworzno", said Mr. Mozer. ${ }^{4}$

The story, from which the quote came, entitled Jaworzno, was autobiographical in nature. Mrożek reminisced there one of his journalist field trips. ${ }^{5}$ The words spoken by Mr. Mozer, the driver, were directed at him, sitting in the back seat of the company's car Skoda.

"I was twenty-one", said the narrator (and the author) of Jaworzno, "and a miracle had just occurred: from a poor high school graduate, a failed student - farewell higher education, from a homeless rebel - farewell parish family, behold I, Lord Byron, I was elevated to Mr. Editor with a car, yes, a car". ${ }^{6}$

If one adds the twenty-one years of age referred therein to Mrożek's date of birth (1930), the resulting year would be 1951, or more precisely, as in another section of the story a specific month was indicated, November 1951.

Symptomatically, Mr. Mozer, usually silent while driving, only used the name of the town. Thus Mrożek indicated or suggested that it functioned similarly to how Oświęcim [Auschwitz] had a few years earlier, as a synecdoche of a camp. Mr. Mozer's surprising dictum provoked Mr. Editor to reflect:

${ }^{3}$ C. Miłosz, "Rzeka”, in: ibid., Ocalenie, Spółdzielnia Wydawnicza Czytelnik, Warsaw 1945, p. 75. [English version translated from Polish]

${ }^{4}$ S. Mrożek, "Jaworzno", Kultura 1985, issue 1/2, pp. 33-34. [English version translated from Polish]

${ }^{5}$ Cf.: "My new function [at the editorial board of «Dziennik Polski»-A.M.] consists of going away for a few days to various towns to «analyse the field». «The field» - that was a new codeword used at that time by all newspapers" (S. Mrożek, Baltazar. Autobiografia, Oficyna Literacka Noir sur Blanc, Warsaw 2006, p. 161). [English version translated from Polish]

${ }^{6}$ S. Mrożek, Jaworzno, p. 32. 
I did know, I had to know that there is a Labour Camp in Jaworzno, one of the Labour Camps, though I did not know, how did I know that, the place where the enemies of the system, the dregs, and parasites are subjected to re-education through useful labour. But that, though just and therefore laudable, was not written about anywhere, so no one spoke of it.?

In the autumn of 1951, the camp in Jaworzno had a long six-year history. The internee re-education process was started by the so-called people's government probably in the February of 1945 . However, the history of the camp located there was much longer. The Central Labour Camp in Jaworzno, that was the official name of the institution since April 1945, ${ }^{8}$ was, in fact, established in the same place where from 15 June 1943 until January 1945 there operated the Arbeitslager Neu-Dachs, a branch of the Auschwitz concentration camp. ${ }^{9}$ The communist authorities took over the preserved infrastructure of the Nazi camp, expanded it in the following years, and added branches. ${ }^{10}$ The liberated on 19 January 1945 by the Red Army four hundred sick internees unable to march ${ }^{11}$ were soon replaced by new internees. Initially, only Germans were interned there (both POWs and civilians, including women and children), Volksdeutsche, persons suspected of collusion with Nazi occupation forces, soldiers of the Polish anti-communist underground, and common criminals. In time, the internees also included persons sentenced by the Special Commission for Combating Economic Abuse and Sabotage (Komisja Specjalna do Walki z Nadużyciami i Szkodnictwem Gospodarczym), and persons associated with the Ukrainian Insurgent Army or those suspected of collusion with it, as well as the Ukrainian and Lemkos population relocated within Operation Vistula. ${ }^{12}$

The Central Labour Camp in Jaworzno fulfilled various functions. It was both, as indicated by its official name, a labour camp, and a POW camp, a penal

${ }^{7}$ Ibid., p. 34.

8 "On 25 April 1945, [...] four so-called central labour camps were established. They were located in Warsaw, Krzesimów (Lubelskie Voivodship), Potulice (Pomorskie Voivodship), Jaworzno (Krakow Voivodship)" (B. Kopka, Obozy pracy w Polsce 1944-1950. Przewodnik encyklopedyczny, Niezależna Oficyna Wydawnicza Nowa, Ośrodek „Karta”, Warsaw 2002, p. 43). [English version translated from Polish]

${ }^{9}$ Vide F. Piper, "Podobóz KL Auschwitz «Neu-Dachs» w Jaworznie 1943-1945", in: Obóz dwóch totalitaryzmów. Jaworzno 1943-1956. Materiaty z konferencji naukowej „Historia martyrologii i obozów odosobnienia w Jaworznie w latach 1939-1956", $2^{\text {nd }}$ edition amended, [vol. 1], K. Miroszewski, Z. Woźniczka (eds.), Muzeum Miasta Jaworzna, Jaworzno 2007, pp. 14-28; P. Setkiewicz, "Podobóz Neu-Dachs w Jaworznie", in: Obóz dwóch totalitaryzmów. Jaworzno 19431956. Katalog wystawy, A. Rams (ed.), Muzeum Miasta Jaworzna, Jaworzno 2014, pp. 19-39.

${ }^{10}$ Vide K. Miroszewski, "Powstanie i funkcjonowanie Centralnego Obozu Pracy w Jaworznie (1945-1949)", Dzieje Najnowsze 2002, issue 2, pp. 23-40.

11 "All internees capable of marching totalling 3,200 people were led out of the subcamp on 17 January 1945 escorted by SS officers and [...] were sent to KL Gross-Rosen” (F. Piper, op. cit., p. 27). [English version translated from Polish]

${ }^{12}$ Vide K. Miroszewski, Powstanie i funkcjonowanie..., p. 25; Bogusław Kopka, op. cit., pp. 126-127. 
camp, and a relocation camp. It did not fulfil all those functions simultaneously. Was it also a concentration camp? Zygmunt Woźniczka argued that the Polish

so-called labour camps were often basically concentration camps where the living conditions and mortality, particularly in 1945, were not much different from that in Nazi KLs or Soviet gulags. [...] Through the use of the misleading name, the security offices or the administration tried to conceal the actual tragic image of Potulice, Sikawa, Świętochłowice, Łambinowice, Jaworzno, and many other "labour camps". ${ }^{13}$

The Central Labour Camp in Jaworzno was the largest camp in Poland. Among all the camps forming the Polish Gulag Archipelago, ${ }^{14}$ it claimed the most victims. The figures are difficult to define. The List of persons who died in Polish prisons in 1944-1956 indicates that in Jaworzno (and its branch camps) the total number of deaths amounted to 6,987 ; however, the figure is surely underestimated ${ }^{15}$. Let us return to Mrożek.

During the vacation period of 1948, the future writer was drafted, as he referred to it, "within an army procedure [...] for compulsory labour camp". ${ }^{16}$ In other words, he received a call to appear at a brigade of Stużba Polsce (Service for Poland) National Organisation. Being a young draftee, he worked on the construction of an army airfield in Boernerowo n. Warsaw. He worked hand in hand, or rather side by side, with German POWs, possibly brought there (specifically: to the Warsaw-Boernerowo camp) ${ }^{17}$ in the early 1948 from the Central Labour Camp in Jaworzno. ${ }^{18}$ Young draftees were not allowed to talk to them.

"I was surprised", wrote Mrożek in his autobiographical story entitled Szyny, "by the paper -whiteness of their skin, and their swelling - today I know it could had been starvation oedema or any type of vitamin deficiency - and the blank sight. They peered as if into the distance, but they could not see anything". ${ }^{19}$

Who, then - it seems the appropriate time to ask - did Mrożek see in the November of 1951? If one reads Jaworzno as a document (memoir), one must assume he saw the so-called juvenile internees. In the late-1940s, the Central Labour Camp in Jaworzno started transforming into a prison for juvenile political prisoners. Thus began another stage in the twelve-year, first Nazi brown, then

${ }^{13}$ Z. Woźniczka, "Centralny Obóz Pracy w Jaworznie na tle stalinowskiego systemu represji (1945-1950)”, in: Obóz dwóch totalitaryzmów. Jaworzno 1943-1956..., vol. 1, p. 94. [English version translated from Polish]

${ }^{14}$ K. Miroszewski, "Miejsce Centralnego Obozu Pracy Jaworzno w polskim systemie więzienno-obozowym”, in: Obóz dwóch totalitaryzmów. Jaworzno 1943-1956. Katalog ..., p. 47.

${ }^{15}$ Vide B. Kopka, op. cit., p. 128.

${ }^{16}$ S. Mrożek, "Szyny", Gazeta Wyborcza 1997, issue 202, p. 15.

${ }^{17}$ Vide M. Łuszczyna, Mała zbrodnia. Polskie obozy koncentracyjne, Znak, Krakow 2017, p. 133.

${ }^{18}$ Vide K. Miroszewski, Powstanie i funkcjonowanie..., p. 31.

${ }^{19}$ S. Mrożek, Szyny, p. 15. [English version translated from Polish] 
communist red, history of the longest operating camp in Poland. The official name of the modified institution was Jaworzno Prison. It was hardly adequate. The prison continued to rather resemble a labour camp than a classical penal facility:

"According to former internees", according to Krzysztof Szwagrzyk, "the term «prison» could be used only in reference to the place of quartering. A significant number of the juveniles spent the most of each day at the place of labour - therefore, the use of the term camp in reference to Jaworzno is absolutely justified". ${ }^{20}$

The camp for the juvenile inmates operated in 1951-1955, and was the biggest such institution in Poland. Thousands of young people were subjected there to not only debilitating labour, but also to indoctrination according to the methods developed by the Soviet pedagogue Anton Makarenko. That experimental penal unit, which no longer had bars in the windows, yet electric fence, a high wall, and guard towers still remained, stopped operating on 31 December 1955. By 31 August 1956, there operated the Jaworzno Central Prison; it received solely juvenile inmates convicted of common crimes. In the autumn of 1951, i.e. during the time referred to in Mrożek's story, the largest group of Jaworzno inmates consisted political prisoners. ${ }^{21}$ They were forced to work in, e.g. mines: "To the notorious Feliks inclined mine, located approx. $3 \mathrm{~km}$ from the prison, juvenile inmates were led on foot". ${ }^{22}$ Just like in Jaworzno.

"Mr. Mozer," Mrożek continued his story,

"drove me - by accident or intentionally - along a high, a very high wall, topped with lines of barbed wire with guard towers on thin legs, while on top of the towers, quite high now, green figures". Mr. Mozer said:

"Brand new, fuck!". ${ }^{23}$

I have already mentioned that Jaworzno is an autobiographical story. It surely is not a verbatim record in every detail; it reports mainly on the situation of the author as the eulogist of the new reality - turning a blind eye to what was not to be seen. In Baltazar, raising the topic of field trips, Mrożek recollected:

you had to get quite before dawn. We would meet up at the car: the driver, Jan Kalkowski, the photographer and I. The car was old, seized from the Nazis, for several people; initially, it was used as a radio broadcast station. ${ }^{24}$

${ }^{20}$ K. Szwagrzyk, Jaworzno. Historia więzienia dla młodocianych więźniów politycznych 1951-1955, „Jaworzniacy” - Fundacja Pomocy Byłym Młodocianym Więźniom Politycznym Lat 1944-1956, Wydawnictwo Klio, Warsaw-Wrocław 1999, p. 43. [English version translated from Polish]

${ }^{21}$ Ibid., p. 72, 199.

${ }^{22}$ Ibid., p. 155.

${ }^{23}$ S. Mrożek, Jaworzno, pp. 35-36.

${ }^{24}$ S. Mrożek, Baltazar..., p. 161. [English version translated from Polish] 
The story features only the driver and the $I$, as well as a car, though a passenger car, not a truck. It is possible that Mrożek assigned Mr. Mozer some of Kalkowski's features, whom he referred to in Baltazar as "he kept a slightly mocking attitude towards everything, depending on the circumstances, or sometimes against the circumstances". ${ }^{25}$ In any case, the specific character of Mr. Mozer was necessary to amplify the dramatic reading of the story, which was the author's way of coming to terms with his once blind engagement in communism (note that the name Mozer is a partial anagram of the name Mrożek - Mozer could thus be considered as the abjured critical aspect of Mrożek's personality). The grim landscape of Jaworzno, then, with inscribed therein non-humans moving along the road, constituted a good excuse for that discussion, as well as an introduction to a more general reflection on the theme of submissiveness to an ideology - leading to overlooking obvious and real things. Jaworzno was, one could conclude, a fictionalisation of a reflection offered in Mrożek's Rozmowa (Interview - with himself) published four years prior.

The writer's statement on his entanglement in ideology provided therein arouses, due to its candour, respect. Even if one considers it a type of a game or a gesture intended to once and for all end any debates regarding his inglorious past, ${ }^{26}$ its honesty is noteworthy, particularly when compared to the statements by other Polish writers who tried to justify themselves, often in complicated ways. In response to a question posed by himself: "Why did you support a totalitarian ideology?" Mrożek said:

Because I wanted to. [...]

Whoever says that she/he overlooked the consequences of an implemented totalitarian ideology - demands for herself/himself to be considered an idiot. Though their calculations are different. She/He proposes to be assigned to honourable status of an idealist, the more of an idealist and the more noble a human the less she/he noticed the ugly obviousness and reality. Paradoxically: their nobility is to be emphasised by the very fact (alleged) that they did not notice the crime. The more they overlooked the crime, the more noble and the bigger idealist they ought to be. For some reason (which I shall not try to find now) the status of an idealist enjoys general esteem regardless of the type of the related ideals. It also comes in handy for those who have it when it is best to extricate oneself from responsibility. Idealists get forgiven everything because they are idealists. ${ }^{27}$

${ }^{25}$ Ibid., p. 164. One can also learn from it that Kalkowski "Was afraid of people in plain clothes, but most of all in uniform" (ibid.). Let me add that during WWII, Kalkowski was wanted by Gestapo, he participated in the Warsaw Uprising, while in later years, he worked at Przekrój developing, e.g. the widely read section Humor zeszytów szkolnych (Bloomers from school notebooks) - vide P. Dubiel, “Jan Karol Kalkowski”, Zeszyty Prasoznawcze 1989, issue 4, pp. 5-10.

${ }^{26}$ Apart from engaged journalistic material, it consisted of signing the Krakow resolution of the division of the Polish Writers' Union, which condemned persons convicted in the fake Krakow curia trial.

${ }^{27}$ S. Mrożek, "Rozmowa", Dialog 1981, issue 2, p. 140. [English version translated from Polish] In that context, it is worth quoting the statements by other writers, e.g. Jarosław Marek 
In an essay entitled Popiót? Diament? published after the release of Rozmo$w a$ and before the printing of Jaworzno, Mrożek confessed that what led him to idealism were his complexes:

In the spring of 1950, I had a revelation [...] I received a magic ring, a magic wand, and a spell which solved my crisis and replaced it with a sense of omnipotence and omniscience. There is, indeed, something magical in how totalitarianism changes a wretched, undertaught, frustrated, and waifish squirt into a wise man and a giant. ${ }^{28}$

Not being, obviously, an idiot, Mrożek was during the time of the field trips one in a legion of the so-called useful idiots. He saw what he wanted to see, while he was not able to notice, or rather absorb, what the usually silent Mozers saw, whether they wanted to or not. He thus stated in Jaworzno:

Of course about all those prisons, camps, or even certain basements of certain state institutions I knew even before. Everyone knew, you couldn't not know. But you could not know that you knew. If it had been public knowledge - it would have be difficult not to know that you knew. ${ }^{29}$

In 1997, Stanisław Lem concluded that he only learnt about the labour camp in Jaworzno where "various class enemies were harassed" 30 from his friend Sławomir Mrożek. He argued:

I knew nothing even about the existence of the camp. I am not saying that to explain myself. I am simply admitting that you lived in a small circle of friends and acquaintances, and so only when October ' 56 came $[\ldots]^{31}$

Maybe Lem did not know what was happening in Jaworzno located less than $60 \mathrm{~km}$ from Krakow. (Ironically enough in 2014, a street located about a kilometre from the former camp was named after Stanisław Lem). ${ }^{32}$ Either way, when one

Rymkiewicz: "I was a juvenile idiot. Simple: brought up by the school and ZMP [Union of Polish Youth - J.W.]", and Julian Stryjkowski: "I did not see that. You can believe me or not, I did not see or feel that, I felt [in Stalinist Poland - A.M.] like at home" (J. Trznadel, Hańba domowa. Rozmowy z pisarzami, Wydawnictwo Test, Lublin 1990, pp. 124, 156-157). [English version translated from Polish]

${ }^{28}$ S. Mrożek, "Popiół? Diament?”, Kultura 1983, issue 1/2, p. 34. [English version translated from Polish]

${ }^{29}$ S. Mrożek, Jaworzno, pp. 36-37.

${ }^{30} \mathrm{~S}$. Lem, statement during a Polish Radio show Zapiski ze współczesności, http://ninateka. pl/film/stanislaw-lem-zapiski-ze-wspolczesnosci-3-5 [accessed on 12.11.2016]. [English version translated from Polish]

${ }^{31}$ Ibid.

${ }^{32}$ The Statement of Reasons to a resolution passed to name the street reads: Lem's works include references to the condition of contemporary society, scientific and philosophical reflection on it, and a criticism of the socialist system", http://www.jaworzno.pl/pl/rada_miejska/konsultacje_ spoleczne/dokument/146/ulica_stanislawa_lema.html [access on 18.11.2016]). [English version 
travelled in that time the road between Krakow and Katowice, one could not not notice the five-metre-high wall erected along it in Jaworzno. It is significant that the decision to close the prison for juveniles was made due to the prison's unfortunate location by one of the most frequented routes in Poland, which linked the two flagship constructions of the six-year plan: Lenin Steelworks and Jaworzno II Power Plant. ${ }^{33}$ In relation to Mrożek's conclusions on the fact of not knowing that one knows, and - may I add - not knowing that which is clearly visible, let me note that the largest number of forced labour camps were developed in the Silesia-Dąbrowa and Krakow Voivodships. ${ }^{34}$ In the early 1950s in Jaworzno, what people mainly saw was that a power plant was being built.

Mrożek was, as is commonly known, the author of an enthusiastic report on the young people building Nowa Huta. ${ }^{35}$ It gave him a permit for field trips. ${ }^{36}$ ZMP youth engaged in the construction of the Jaworzno II power plant, which would not be fulfilled without the help of the Soviet nation, were reported upon by his colleagues penetrating the field, i.e. Michał Słomczyński and Stanisław Stanuch, and a poet Andrzej Mandalian. ${ }^{37}$ None of them made any references to the inmates. That does not mean, however, that the press remained consistently quiet about the camp.

Let us move a few years back. Between July and August 1946 in the Warsaw-based Express Wieczorny and the Łódź-based Kurier Popularny, there appeared a report on the camp in Jaworzno. ${ }^{38}$ It was devoted to the Volksdeutsche (foksy)

translated from Polish] I am obliged to add that among his works, there were such which supported the system, too.

${ }^{33}$ Vide K. Szwagrzyk, op. cit., p. 200.

${ }^{34}$ Vide K. Miroszewski, Powstanie i funkcjonowanie..., p. 24.

${ }^{35}$ S. Mrożek, "Młode miasto", Przekrój 1950, issue 276, p. 8. Szwagrzyk recalled that Mrożek was the author of the earliest publications on the "pedagogical experiment" fulfilled at the Jaworzno prison; they were supposed to be published in Sztandar Młodych in 1951-1955 (op. cit., p. 15). Corresponding note: "S. Mrożek, «Sztandar Młodych» (1951-1955) - issue could not be defined", suggested, however, that the historian had never seen the referred publication before. When asked by me about the address of Mrożek's publication regarding Jaworzno, in an e-mail addressed to me of 29 Nov 2016. Prof. Szwagrzyk responded that after so many years after writing the monograph, he could no longer recreate the sources. I looked through the indicated years of Sztandar Młodych, but I could not find there any texts on the Jaworzno prison; they did, however, include articles devoted to the Jaworzno II power plant (none of them were signed by Mrożek or a name similar to his nom de plume, tough).

${ }^{36}$ Vide H. Stephan, Mrożek, Wydawnictwo Literackie, Krakow 1996, p. 44.

${ }^{37}$ M. Słomczyński, "Turbiny imienia Stalina”, Życie Literackie 1953, issue 12, p. 2; S. Stanuch, "Zwycięstwo nie ma skrzydeł", Pokolenie 1953, issue 32, pp. 6-7; A. Mandalian, "Wieczór w Jaworznie", in: A. Braun, A. Mandalian, W. Woroszylski, Wiosna sześciolatki. Wiersze, Książka i Wiedza, Warsaw 1951, pp. 39-42. All those texts constituted, similarly to Mrożek's report, model products of ideology.

${ }^{38}$ It was published in two slightly different versions; each received a different title: "Za drutami, w których nie czai się śmierć. Pod strażą, która nie katuje, pracują w Jaworznie volksdeutsche”, 
held therein, who at that time were the largest group of internees, ${ }^{39}$ and, to a much lesser degree, German POWs. Other categories of inmates were passed over with silence. A probable cause for raising the topic in the press was the expected visit of the commission of the International Red Cross and the International Labour Organisation, which were to verify the living conditions in Polish camps. In the case of Jaworzno, they were reprehensible. The guards abused the inmates:

For the slightest offence, inmates were beaten, and placed in detention filled with water and broken glass. At night, inmates were taken outside, and kept there in freezing temperatures. They were also ordered to lay on the floor while other inmates were ordered to jump off stools onto their backs. ${ }^{40}$

In 1945, five thousand people died at the camp, a year later a thousand fatalities was recorded. ${ }^{41}$ The bodies were buried in secret in the nearby forest. Nonetheless, news of the camp spread quickly even reaching foreign media. ${ }^{42}$ The communist authorities were thus forced to react, and they did so in a manner typical of them. The camp was presented in a report as a virtually idyllic place:

Having seen camp life, and having observed the enthusiasm and the spirit with which the inmates engage in work, one soon realises that the only and sole penalty those people are given is imprisonment. That is it. ${ }^{43}$

The prison infirmary is empty because none of the inmates get sick, there are plants on window sills; the food is plentiful, and the camp has a pitch and a swimming pool.

Several years later when the Central Labour Camp in Jaworzno was renamed to Jaworzno Prison, Trybuna Ludu published a report by Janina Borowska entitled Twarda szkoła ludzi. It mentioned a "grim detail" in the townscape of Jaworzno: "a thick brick wall, and behind it... incarcerated youth". ${ }^{44}$ It stated that some inmates served time for their anti-state activities. It also referred to mining work older youths had to perform: "It is a tough work, but it builds character". ${ }^{5}$

Express Wieczorny 1946, issue 71, p. 2; “Odmieniły się role, ale tylko częściowo. Odwiedzamy obóz pracy dla «foksów» w Jaworznie", Kurier Popularny 1946, issue 210, p. 4.

${ }^{39}$ Vide A. Dziurok, "Volksdeutsche w Centralnym Obozie Pracy w Jaworznie", in: Obóz dwóch totalitaryzmów. Jaworzno 1943-1956..., vol. 1, p. 60.

${ }^{40}$ Ibid., p. 58.

${ }^{41}$ Vide ibid., p. 60.

${ }^{42}$ The news of how the camps of the Ministry of Public Security functioned were delivered to the West by bishop Stanisław Adamski - vide M. Łuszczyna, Mała zbrodnia ..., p. 48.

${ }^{43}$ Odmienity się role..., p. 4. [English version translated from Polish]

${ }^{44}$ J. Borowska, "Twarda szkoła ludzi”, Trybuna Ludu 1955, issue 55, p. 4. [English version translated from Polish]

${ }^{45}$ Ibid. 
Borowska's text was, basically, a socialist realist tale, the main focus of which were the struggles of the pedagogues, and the resulting grand project of resocialising those who lost their way. It was printed on 25 February 1955, less than three months prior to an inmate mutiny, the biggest such event in the prisons of the PRL (People's Republic of Poland), which proved the utter failure of the pedagogical experiment undertaken in Jaworzno. I shall return to it later on.

One should assume that Twarda szkola ludzi was symptomatic of what the never published reports by writers who visited the prison for juveniles in Jaworzno looked like. Those special visits were referenced in a 1961 article by Zdzisław Jędrzejewski, former head of Jaworzno Prison, published in Przegląd Więziennictwa. It stated that:

Based on Makarenko's thesis that "labour itself without the simultaneous education, without the simultaneous political and social teaching, does not result in any educational benefits, and is a neutral process", in Jaworzno there were introduced all permissible and organisable in the prison conditions forms of cultural and educational work. ${ }^{46}$

\section{"Particularly interesting are", continued lieutenant Jędrzejewski,}

"the meetings with the authors of the most read contemporary books, combined with discussions of their works. Jaworzno was visited by: Maria Jarochowska, Igor Newerly, Stanisław Wygodzki and Kazimierz Koźniewski. The biggest discussions arose over the books: Pamiatka $z$ [C]elulozy [by Newerly] and Piątka z ulicy Barskiej [by Koźniewski]. Those meetings constituted an unforgettable experience both for the inmates who participated in them directly, and for those listened in on the radio [broadcast via the PA system - A.M.]. They cemented the inmates sense of being human, of someone about whom their homeland cares, and who could take their appropriate place within the society upon having suffered for their crimes. ${ }^{47}$

${ }^{46}$ Z. Jędrzejewski, “Pierwszy zakład karny dla więźniów młodocianych w Polsce. «Jaworzno»”, Przegląd Więziennictwa 1961, issue 2, p. 32. [English version translated from Polish]

${ }^{47}$ Ibid. Thus wrote the former head of prison: "We gained good results from talks on Polish literature, which discussed the progressive traditions of our literature. Many inmates learnt for the first time in their lives about the revolutionary activities of specific writers, whose views they had previously only perceived in a completely different light. [...] An important role in their education, and the influence on inmates should be assigned to the literature club, which focussed on stimulating inmates to engage in independent creative attempts. Thus formed works, usually centring on the themes close to them, e.g. war-time experiences, transformations, and the reasons behind their conflicts with the law, were announced over the PA system. Some, e.g. a short story entitled Kuźnia, which discussed the transformations of a juvenile inmate, and poems: To nie Plewa [a poem based on a film entitled Pierwsze dni, which was an adaptation of a novel by Bogdan Hamera entitled $\mathrm{Na}$ przykład Plewa - A.M.] and Marzycielom o amnestii poświęcam, which condemned inmates who did not apply themselves to work as they expected amnesty were largely popular and appreciated by some and condemned by others. The clash of people's views resulting from those works considerably influenced the cementing of positive attitudes, and inspired inmates to engage in cultural and educational life" (ibid., pp. 32-33). 
Political prisoners differed in terms of how they perceived those meetings: Taduesz Mróz reminisced that for him they were the biggest moral harassment, ${ }^{48}$ while Tadeusz Lustig, when discussing Newerly's visit, showed some tolerance:

you could see that he did not come to us only due to his party duty; he actually wanted to establish some closer connection with us. Or maybe he intended to write something on the thousands of young boys thrown behind bars? ${ }^{49}$

Indeed, Newerly, both a writer and a pedagogue, had such a plan. He was not the only one. Other enthusiasts of the experimental prison in Jaworzno, e.g. Jarochowska, Wygodzki, and Koźniewski, had similar ideas. The last of the three reminisced years later:

Every one of us writers (Wygodzki, Jarochowska, and a few others) who were invited to meet the author sessions with the inmates at Jaworzno had to commit that whatever we may later write, it had to be approved by minister [of national security - A.M.] Radkiewicz for publication.

We all wrote such reports, and in addition, I wrote a large and very enthusiast one, but non of those reports were ever published. As for me, the explanation, slightly humorous, was as follows:

"The report leads to believe that the prison in Jaworzno was the most beautiful place in Poland..." ${ }^{\circ 0}$

In 1968, another work by Koźniewski was published, a novel entitled Bunt $w$ więzieniu, which was inspired with the already mentioned mutiny of juvenile inmates, which broke out on 15 May 1955. It was triggered by a guard shooting an inmate who was resting after work near the so-called dead zone. For many years Koźniewski's book was considered a literary document on the camp while its author an expert on Jaworzno. ${ }^{51}$ It was re-issued twice: in 1972 and 1985. Both former inmates and Krzysztof Szwagrzyk, the author of the monograph on the prison for juveniles, agreed that the events presented therein had nothing to do with the reality apart from the fact that the mutiny took place..$^{52}$ The mutiny, may I add, was spontaneous in nature: the inmates, in response to the death of their fellow prisoner, tried to set fire to the guard tower from which the shot was taken, they pelted rocks at it, they broke the electrified fence, and they beat up one of the "teachers". In the novel, however, the mutiny was planned. It was

${ }^{48}$ T. K. Mróz, "Niepokorni - młodociani więźniowie polityczni z lat 1944-1956”, in: Obóz dwóch totalitaryzmów. Jaworzno 1943-1956..., vol. 1, p. 148.

${ }^{49}$ T. Lustig, Orlęta w Jaworznie. Kartki z pamiętnika, Księgarnia Akademicka, Krakow 1997, p. 92. [English version translated from Polish]

${ }^{50}$ K. Koźniewski, statement, in: Grażyna Kuźnik, op. cit., pp. 54-55. [English version translated from Polish]

${ }^{51}$ Zob. M. Wyrwich, op. cit., p. 159.

${ }^{52}$ Vide K. Szwagrzyk, op. cit., pp. 10, 195-199. Vide also: M. Wyrwich, op. cit., pp. 152-164. 
started by political prisoners because they were not included in the recent amnesty. Having guns at their disposal, they killed several guards in cold blood. The mutiny which was started with freedom in mind immediately turned into its opposite; the elevated upsurge was soon replaced by savagery, lynching, and, committed by regular criminals, a gang rape on the female employees of the prison chancellery. It should be added that the novel offered additional two actual facts: a piece of information that the prison in Jaworzno "dramatically deteriorated" 53 since common criminals started to be sent in, and the emphasised in it fingering common among the inmates and supported by the "teachers".

Koźniewski rejected the, as he called them, "pointless claims" that he stated untruths, posed against him many years later stating that he wrote a novel "about a completely made-up inmate mutiny in a made-up prison in a made-up town". ${ }^{4}$ However, his responses were unconvincing, as is common for anyone who uses literature for ideological purposes, and later, when the wind starts blowing from a different side, tries to convince their readers that their work, as apparently any work of literature, is autarkic in nature. The best proof of Koźniewski's belief in the fact that writers and their works can model social life was his long-time "service" (1947-1989) as a secret collaborator of UB and SB (secret police institutions in the PRL) which survailed the writers' community, one of the most devoted and the most valuable ones. ${ }^{55}$ In any case, Koźniewski, not only a writer but also an activist of the Polish Scouting and Guiding Association (ZHP), i.e. a teacher, was truly bewitched by the Jaworzno Prison. Many years later he concluded: I spent three days there, I talked to warden Piątkowski, and a dozen or so of the boys. I know they had hobby clubs, musical bands, a cinema, and a theatre...". ${ }^{56}$ However, the goal of the prison in Jaworzno was not to aid the inmates' spiritual development, but to "break the disobedient youth, and - as one of the officers

${ }^{53}$ K. Koźniewski, Bunt w więzieniu, Czytelnik, Warsaw 1968, p. 204.

${ }^{54}$ K. Koźniewski, Stownik swoich i obcych, Iskry, Warsaw 1994, p. 8. [English version translated from Polish] He introduced a similar protection already in the self-commentary included in the novel: "It is [...] a regular novel. Maybe even a fantasy novel... In terms of truth, the author shall not accept any complaints" (Bunt w więzieniu, p. 15).

${ }^{55}$ Vide S. Cenckiewicz, P. Gontarczyk, "Konfident z wyboru", Wprost 2006, issue 24, pp. 38-40; J. Siedlecka, “Agent «33»- na swoich i obcych (Kazimierz Koźniewski)”, in: ibid., Kryptonim „Liryka”. Bezpieka wobec literatów, Prószyński i S-ka, Warsaw 2008, pp. 155-201. In a diary entry of 6 September 1955, Andrzej Kijowski included the following remark regarding Koźniewski: "He could hold files on all political activists in Poland. How does he know all that? He announces journals which he will publish in five years' time. Well, well... I will never forgive him how he told me in amazement three years ago about a penal camp for the youth in Jaworzno, which he visited, only to write a report «at the commission of the Ministry of Public Security». How can anyone write reports commissioned by the MPS?" (ibid., Dziennik 1955-1969, K. Kijowska and J. Błoński (selection and editing), Wydawnictwo Literackie, Krakow 1998, p. 60). [English version translated from Polish]

${ }^{56}$ K. Koźniewski, statement, in: Mateusz Wyrwich, op. cit., p. 160. 
recalled - «to turn them into a force of low-paid snitches for the security institutions, ORMO, and the police»" ${ }^{57}$ Koźniewski was surely aware of that as he was an intelligent person; the thing is, though, that the "educational principle" which results in fingering must have been to his, a habitual snitch's, liking.

It should also be added that in 1959, Koźniewski's novel entitled Zimowe kwiaty was published; it presented the difficult process of adapting to life outside prison of a young man released from the prison in Dębów, where he served time "for politics". His social acceptance is hindered by his prison-developed... political practice, ideology, and uncompromising nature. Dębów was based on an image of Jaworzno idealised by the writer. He thus wrote about the inmates included in the amnesty, who included Karol Białous, the novel's protagonist:

They lived long enough in isolation from everyday life, raised in an artificial cushioned atmosphere of the model prison, a house without bars, for them not to feel the urge to confront their dreams and plans with the fate of the rest of the society. They idealised that which remained behind the wall. In the prison, they formed a group of friends excelling at everything: in cell tidiness, in learning, in culture work. [...] Their cell was the meeting point for boys from the entire floor flocking for ideological disputes;

Karol returned from Dębów filled with the greatest dreams of man's socialist happiness. ${ }^{58}$

An earlier, and at the same time a more honest, image of the prison in Jaworzno was offered by the story entitled Amnestia zastukata do bram by Seweryna Szmaglewska, published in 1956 in Po prostu. When writing it, she must have used an account of a former inmate. According to the historian, the events described in it basically correspond to the accounts of those who participated in the mutiny. ${ }^{59}$ The story, however, did not only discuss the mutiny.

Its main protagonist Grzegorz was an inmate recently released in the amnesty. Based on his confessions made to Jerzy, a sculptor and a former Auschwitz prisoner, one learns that after the Warsaw Uprising he was sent, still a child, to German camps. Upon returning to Poland, when he grew up, he discovered a community vein so he joined ZMP. Soon, though, he became associated with an illegal organisation. Once it was exposed, he was convicted of an attempted overturning of the democratic system of the Polish state. He served his sentence in several locations, in Jaworzno the longest. "It is a good prison. The best there is. Youthful", ${ }^{60}$ he said. He also talked about the mutiny. Having listened to Grzegorz, Jerzy could

${ }^{57}$ A. Fedorowicz, "Przymusowy obóz pracy w Jaworznie. Wzorowy polski łagier", Polityka 2014, issue 2, p. 57.

${ }^{58}$ K. Koźniewski, Zimowe kwiaty. Powieść współczesna, Państwowy Instytut Wydawniczy, Warsaw 1959, p. 24, 47. [English version translated from Polish] Karol Białous was mentioned in Bunt w więzieniu, as a person released from prison (p. 195).

${ }^{59}$ K. Szwagrzyk, op. cit., p. 196.

${ }^{60}$ S. Szmaglewska: "Amnestia zastukała do bram”. Po prostu 1956, issue 46, p. 5. [English version translated from Polish] 
not hide his outrage: "Jaworzno, a branch of Oświęcim, was appropriated for our citizens", ${ }_{11}$ "Thus a monument to Oświęcim was preserved in Jaworzno!" ${ }^{2}$ Significantly enough, the sculptor had previously foregone taking part in a competition for an Auschwitz monument as he could not find an adequate expression for the crimes committed there. In conclusion of his "confession", Grzegorz said to him:

We live [...] in an epoch of naive leaders. They think that truth is not permeating to the nation when they smother it behind bars, suppress it, force into people's mouths. The idiots forget then that the truth even leaves crematoriums. It runs between people like an epidemic. It expands. Some get paralysed by it. In others it arouses rebellion. ${ }^{63}$

The story by Szmaglewska, a former Auschwitz-Birkenau internee, raised the issue of political prisoners, and, at the same time, it criticised a specific ideology which falsified reality, and its tool: socialist realism. When currently working on a monument devoted to miners, Jerzy radically changed the concept under the influence of the talk with Grzegorz: instead of the heroism of work, he emphasised the horror of the deaths of the miners: inmate miners. Jerzy turned to his colleagues, an architect and urban planner, who accused his projects of pessimism: "Don't you understand $[. .$.$] that from the varnished extreme you inevitably fall into another?$ From the colourful to the black. [...] Art need to notice life". ${ }^{64}$ His sketch for one of the sculptures depicted "a boy with a swollen face, with a shaved head. [...] In front of him, he held a mining lantern. Behind him, in the dark, a rifle pointed in between his shoulder blades". ${ }^{65}$

One fault of Szmaglewska's work, resulting probably from good intentions, was the distortion of the protagonist's biography which suggested that such prisons as Jaworzno received people who lost their way (in terms of ideology). Thus the writer did not question the political system but only the means it used to introduce the principle of social justice. In the story they resembled those which the Nazis once used. In that aspect, Szmaglewska's work was bold, provocative even. Two other sketches prepared by Jerzy, entitled Pożar w kopalni and Gaz, suggested killing inmates in a gas chamber: "Tangled human swarm [...] Screams. Opened mouths. Tight corridors. Low ceiling. [...] The body struggles with the invisible substance, convulses". ${ }^{66}$

Let us return once more to Mrożek. He avowed in Baltazar:

Still, I was lucky I wasn't born German in, say, 1913. I would had been a Nazi because the drafting technique was exactly the same. So where's the luck since there was no bigger

\footnotetext{
${ }^{61}$ Ibid.

${ }^{62}$ Ibid.

${ }^{63}$ Ibid.

${ }^{64}$ Ibid.

${ }^{65}$ Ibid.

${ }^{66}$ Ibid.
} 
difference between Nazism and communism? [...] People like I were once recruited both to Hitlerjugend and to Komsomol in the early heroic periods of both ideologies, before party affiliation became only a matter of opportunism. ${ }^{67}$

\section{Much earlier, Czesław Miłosz posited in The Captive Mind that}

It is possible that the German who locked Beta [i.e. Tadeusz Borowski - A.M.] into the concentration camp was, like him, a disappointed lover of the world who longer for harmony and purity, discipline and faith. ${ }^{68}$

One could therefore ask whether Szmaglewska and, especially, Miłosz and Mrożek did not move in those analogies too far. In my opinion, no. Jaworzno, or more precisely the place where in 1943-1956 a camp (prison) operated, combined two totalitarianisms. ${ }^{69}$ To notice those analogies, all one needs to do is not close her/his eyes. Szmaglewska managed to do it earlier, within the wave of the October thaw, or at least she managed earlier to express it in a world subject to censorship. ${ }^{70}$

\section{A German historian Detlev J.K. Peukert concluded:}

Nazi terror was visible not only during the wave of repressions which accompanied the seizure of power in 1933, and during the so-called Night of Broken Glass (Reichskristallnacht) in 1938, but - in conjunction with the mass extermination conducted in the East, in concentration camps - was identifiable for anyone who could and wanted to see it. Only those who closed their eyes "knew nothing". [...] In almost every city, every commune, during WWII there were camps for foreign forced labourers, POWs, and concentration camp internees. Without diminishing the occasional manifestations of help offered by Germans, one must conclude, though, that the everyday lives of the majority of people remained surprisingly unstirred by the visible suffering, often times happening right in front of their doors. ${ }^{71}$

One could say: that is exactly like in Jaworzno.

${ }^{67}$ S. Mrożek, Baltazar..., p. 149. Mrożek quoted there his statement from a survey in 1987.

${ }^{68}$ C. Miłosz, Captive mind, trans. J. Zielonko, Knopf, New York 1953, p. 133.

${ }^{69}$ Cf.: Obóz dwóch totalitaryzmów. Jaworzno 1943-1956..., vol. 1, op. cit.; Obóz dwóch totalitaryzmów. Jaworzno 1943-1956, vol. 2, R. Terlecki (ed.), Muzeum Miasta Jaworzna, Jaworzno 2007; Obóz dwóch totalitaryzmów. Jaworzno 1943-1956. Katalog....

${ }^{70}$ It is also worth mentioning that Amnestia zastukata do bram has never been reprinted even though its author published a total of three collections of stories in the following years (vide A. Morawiec, Seweryna Szmaglewska (1916-1992). Bibliografia, Wydawnictwo Wyższej Szkoły Humanistyczno-Ekonomicznej, Łódź 2007). It might have been caused by the parallel included in it, which could not be possibly accepted by censorship in the post-thaw period.

${ }^{71}$ D.J.K. Peukert, “Codzienność i barbarzyństwo. O normalności Trzeciej Rzeszy”, in: Nazizm. Trzecia Rzesza a procesy modernizacji, selected and edited by H. Orłowski, trans. M. Tomczak, Wydawnictwo Poznańskie, Poznań 2000, p. 157. [English version translated from Polish] 


\section{Bibliography}

Borowska Janina, “Twarda szkoła ludzi”, Trybuna Ludu 1955, issue 55, p. 4.

Cenckiewicz Sławomir, Gontarczyk Piotr, "Konfident z wyboru”, Wprost 2006, issue 24, pp. 38-40.

Dubiel Paweł, "Jan Karol Kalkowski”, Zeszyty Prasoznawcze 1989, issue 4, pp. 5-10.

Dziurok Adam, "Volksdeutsche w Centralnym Obozie Pracy w Jaworznie", in: Obóz dwóch totalitaryzmów. Jaworzno 1943-1956. Materiaty z konferencji naukowej „Historia martyrologii i obozów odosobnienia w Jaworznie w latach 1939-1956", $2^{\text {nd }}$ edition amended, vol. 1, Kazimierz Miroszewski, Zygmunt Woźniczka (eds.), Muzeum Miasta Jaworzna, Jaworzno 2007, pp. 52-60.

Fedorowicz Andrzej, "Przymusowy obóz pracy w Jaworznie. Wzorowy polski łagier", Polityka 2014, issue 2, p. 54.

Jędrzejewski Zdzisław, "Pierwszy zakład karny dla więźniów młodocianych w Polsce. «Jaworzno»”, Przeglad Więziennictwa 1961, issue 2, pp. 5-53.

Justification [to a resolution of the Jaworzno City Council on naming one of the town's streets after Stanisław Lem], http://www.jaworzno.pl/pl/rada_miejska/konsultacje_spoleczne/dokument/146/ulica_stanislawa_lema.html [accessed on 18.11.2016].

Kijowski Andrzej, Dziennik 1955-1969, selection and editing Kazimiera Kijowska and Jan Błoński, Wydawnictwo Literackie, Krakow 1998.

Kopka Bogusław, Obozy pracy w Polsce 1944-1950. Przewodnik encyklopedyczny, Niezależna Oficyna Wydawnicza Nowa, Ośrodek „Karta”, Warsaw 2002.

Koźniewski Kazimierz, Bunt w więzieniu, Czytelnik, Warsaw 1968.

Koźniewski Kazimierz, Stownik swoich i obcych, Iskry, Warsaw 1994.

Koźniewski Kazimierz, Zimowe kwiaty. Powieść współczesna, Państwowy Instytut Wydawniczy, Warsaw 1959.

Kuźnik Grażyna, Hektary Morela (10 reportaży o COP Jaworzno), [missing publisher, place and year of publication], http://www.sbc.org.pl/dlibra/plain-content?id=73070 [accessed on 18.11.2016].

Lem Stanisław, statement during a Polish Radio show Zapiski ze współczesności, http://ninateka.pl/ film/stanislaw-lem-zapiski-ze-wspolczesnosci-3-5 [accessed on 12.11.2016].

Lustig Tadeusz, Orlęta w Jaworznie. Kartki z pamiętnika, Księgarnia Akademicka, Krakow 1997.

Łuszczyna Marek, Mała zbrodnia. Polskie obozy koncentracyjne, Znak, Krakow 2017.

Mandalian Andrzej, "Wieczór w Jaworznie”, in: Braun Andrzej, Mandalian Andrzej, Woroszylski Wiktor, Wiosna sześciolatki. Wiersze, Książka i Wiedza, Warsaw 1951, pp. 39-42.

Miłosz Czesław, "Rzeka", in: ibid., Ocalenie, Spółdzielnia Wydawnicza Czytelnik, Warsaw 1945, pp. 74-75.

Miłosz Czesław, Captive mind, trans. Jane Zielonko, Knopf, New York 1953.

Miłosz Czesław, Native Realm. A Search for Self-Definition, trans. C.S. Leach, University of California Press, Berkeley 1981.

Miroszewski Kazimierz, "Powstanie i funkcjonowanie Centralnego Obozu Pracy w Jaworznie (1945-1949)", Dzieje Najnowsze 2002, issue 2, pp. 23-40.

Miroszewski Kazimierz, "Miejsce Centralnego Obozu Pracy Jaworzno w polskim systemie więzienno-obozowym”, in: Obóz dwóch totalitaryzmów. Jaworzno 1943-1956. Katalog wystawy,

Adrian Rams (ed.), Muzeum Miasta Jaworzna, Jaworzno 2014, pp. 41-51.

Morawiec Arkadiusz, Seweryna Szmaglewska (1916-1992). Bibliografia, Wydawnictwo Wyższej Szkoły Humanistyczno-Ekonomicznej, Łódź 2007.

Mrożek Sławomir, Baltazar. Autobiografia, Oficyna Literacka Noir sur Blanc, Warsaw 2006.

Mrożek Sławomir, "Jaworzno", Kultura 1985, issue 1/2, pp. 31-39.

Mrożek Sławomir, "Młode miasto", Przekrój 1950, issue 276, pp. 8-9.

Mrożek Sławomir, "Popiół? Diament?”, Kultura 1983, issue 1/2, pp. 33-41. 
Mrożek Sławomir, "Rozmowa", Dialog 1981, issue 2, pp. 140-141.

Mrożek Sławomir, "Szyny”, Gazeta Wyborcza 1997, issue 202, p. 15.

Mróz Tadeusz Kazimierz, "Niepokorni - młodociani więźniowie polityczni z lat 1944-1956", in: Obóz dwóch totalitaryzmów. Jaworzno 1943-1956. Materiały z konferencji naukowej „Historia martyrologii i obozów odosobnienia w Jaworznie w latach 1939-1956”, $2^{\text {nd }}$ edition amended, vol. 1, Kazimierz Miroszewski, Zygmunt Woźniczka (eds.), Muzeum Miasta Jaworzna, Jaworzno 2007, pp. 144-156.

Obóz dwóch totalitaryzmów. Jaworzno 1943-1956, $2^{\text {nd }}$ edition, Ryszard Terlecki, Muzeum Miasta Jaworzna, Jaworzno 2007.

Obóz dwóch totalitaryzmów. Jaworzno 1943-1956. Katalog wystawy, Adrian Rams (ed.), Muzeum Miasta Jaworzna, Jaworzno 2014.

Obóz dwóch totalitaryzmów. Jaworzno 1943-1956. Materiaty z konferencji naukowej „Historia martyrologii i obozów odosobnienia w Jaworznie w latach 1939-1956", $2^{\text {nd }}$ edition amended, vol. 1, Kazimierz Miroszewski, Zygmunt Woźniczka (eds.), Muzeum Miasta Jaworzna, Jaworzno 2007.

“Odmieniły się role, ale tylko częściowo. Odwiedzamy obóz pracy dla «foksów» w Jaworznie”, Kurier Popularny 1946, issue 210, p. 4.

Peukert Detlev. J.K., “Codzienność i barbarzyństwo. O normalności Trzeciej Rzeszy”, in: Nazizm. Trzecia Rzesza a procesy modernizacji, selected and edited by Hubert Orłowski, trans. Maria Tomczak, Wydawnictwo Poznańskie, Poznań 2000, pp. 150-166.

Piper Franciszek, "Podobóz KL Auschwitz «Neu-Dachs» w Jaworznie 1943-1945”, in: Obóz dwóch totalitaryzmów. Jaworzno 1943-1956. Materiaty z konferencji naukowej „Historia martyrologii i obozów odosobnienia w Jaworznie w latach 1939-1956", $2^{\text {nd }}$ edition amended, vol. 1, Kazimierz Miroszewski, Zygmunt Woźniczka (eds.), Muzeum Miasta Jaworzna, Jaworzno 2007, pp. 14-28.

Setkiewicz Piotr, "Podobóz Neu-Dachs w Jaworznie", in: Obóz dwóch totalitaryzmów. Jaworzno 1943-1956. Katalog wystawy, Adrian Rams (ed.), Muzeum Miasta Jaworzna, Jaworzno 2014, pp. 19-39.

Siedlecka Joanna, “Agent «33» - na swoich i obcych (Kazimierz Koźniewski)”, in: ibid., Kryptonim „Liryka”. Bezpieka wobec literatów, Prószyński i S-ka, Warsaw 2008, pp. 155-201.

Słomczyński Michał, “Turbiny imienia Stalina”, Życie Literackie 1953, issue 12, p. 2.

Stanuch Stanisław, “Zwycięstwo nie ma skrzydeł”, Pokolenie 1953, issue 32, pp. 6-7.

Stephan Halina, Mrożek, Wydawnictwo Literackie, Krakow 1996.

Szmaglewska Seweryna, “Amnestia zastukała do bram”, Po prostu 1956, issue 46, p. 5.

Szwagrzyk Krzysztof, Jaworzno. Historia więzienia dla młodocianych więźniów politycznych 1951-1955, „Jaworzniacy” - Fundacja Pomocy Byłym Młodocianym Więźniom Politycznym Lat 1944-1956, Wydawnictwo Klio, Warsaw-Wrocław 1999.

Trznadel Jacek, Hańba domowa. Rozmowy z pisarzami, Wydawnictwo Test, Lublin 1990.

Woźniczka Zygmunt, "Centralny Obóz Pracy w Jaworznie na tle stalinowskiego systemu represji (1945-1950)", in: Obóz dwóch totalitaryzmów. Jaworzno 1943-1956. Materiały z konferencji naukowej „Historia martyrologii i obozów odosobnienia w Jaworznie w latach 1939-1956”, $2^{\text {nd }}$ edition amended, vol. 1, Kazimierz Miroszewski, Zygmunt Woźniczka (eds.), Muzeum Miasta Jaworzna, Jaworzno 2007, pp. 87-113.

Wyrwich Mateusz, Lagier Jaworzno, $2^{\text {nd }}$ edition, Oficyna Wydawnicza Rytm, Warsaw 2013.

"Za drutami, w których nie czai się śmierć. Pod strażą, która nie katuje, pracują w Jaworznie volksdeutsche", Express Wieczorny 1946, issue 71, p. 2. 


\section{Jaworzno. Invisibility}

(Summary)

The article discussed the literary representations of the communist labour camp in Jaworzno (1945-1956), particularly the short story by Seweryna Szmaglewska entitled Amnestia zastukata do bram (1956), a novel by Kazimierz Koźniewski entitled Bunt $w$ więzieniu (1968), and a short story by Sławomir Mrożek entitled Jaworzno (1985). The discussion also applied to the problem of ideological entanglement of Polish literature and Polish writers (particularly during the Stalinist period), and the reasons for their (and the society's) "overlooking" the obvious manifestations of communist terror. Its alleged "invisibility" was analogous to the "invisibility" of the crimes committed by the Nazis, allegedly not noticed by the citizens of the Third Reich. Among Polish writers, that analogy between Nazism and communism was indicated by Mrożek, while the similarities of both totalitarian systems were identified also by Szmaglewska and Czesław Miłosz. 